\title{
Residents' perceptions of environmental certification, environmental impacts and support for the World Expo 2015: the moderating effect of place attachment
}

Article

Accepted Version

Prayag, G., Chowdhury, M., Prajogo, D., Mariani, M. and Guizzardi, A. (2021) Residents' perceptions of environmental certification, environmental impacts and support for the World Expo 2015: the moderating effect of place attachment. International Journal of Contemporary Hospitality Management, 34 (3). pp. 1204-1224. ISSN 0959-6119 doi: https://doi.org/10.1108/IJCHM-06-2021-0824 Available at https://centaur.reading.ac.uk/102038/

It is advisable to refer to the publisher's version if you intend to cite from the work. See Guidance on citing.

To link to this article DOI: http://dx.doi.org/10.1108/IJCHM-06-2021-0824

Publisher: Emerald

All outputs in CentAUR are protected by Intellectual Property Rights law, including copyright law. Copyright and IPR is retained by the creators or other copyright holders. Terms and conditions for use of this material are defined in the End User Agreement. 


\section{www.reading.ac.uk/centaur}

\section{CentAUR}

Central Archive at the University of Reading

Reading's research outputs online 


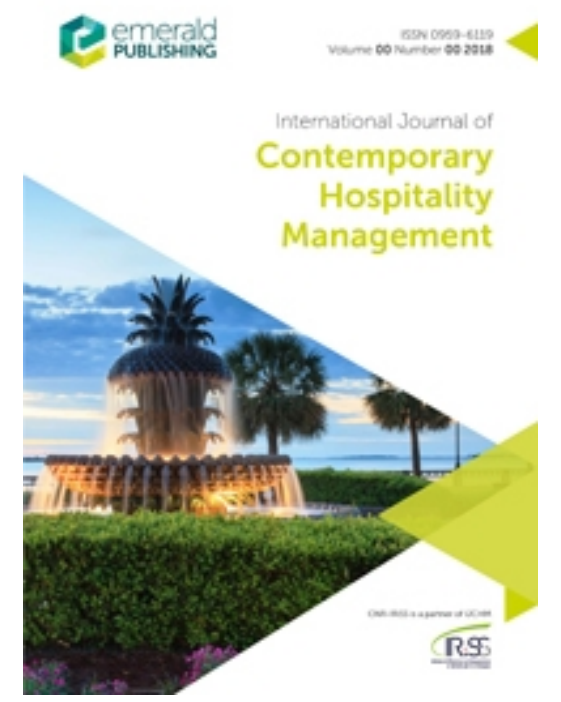

\section{Residents' Perceptions of Environmental Certification, Environmental Impacts and Support for the World Expo 2015: The Moderating Effect of Place Attachment}

\begin{tabular}{|r|l|}
\hline Journal: & International Journal of Contemporary Hospitality Management \\
\hline Manuscript ID & IJCHM-06-2021-0824.R2 \\
\hline Manuscript Type: & Original Article \\
\hline Keywords: & $\begin{array}{l}\text { Event support, Event certification, Environment impacts, Place } \\
\text { attachment, Certification benefits, World Expo }\end{array}$ \\
\hline \multicolumn{2}{|l}{} \\
\end{tabular}

\section{SCHOLARONE ${ }^{m}$ Manuscripts}




\title{
Residents' Perceptions of Environmental Certification, Environmental Impacts and Support for the World Expo 2015: The Moderating Effect
} of Place Attachment

\begin{abstract}
Purpose. Based on social exchange theory (SET) and signaling theory (ST), this study evaluates how an event's perceived environmental certification (PEC) by residents, affect their evaluations of environmental impacts and subsequent event support (ES). The moderating role of place attachment (PA) on some of these relationships is also evaluated. Design/methodology/approach. Using PLS-SEM, a theoretical model is tested on a sample of 450 residents who attended the 2015 Milan World Expo.

Findings. PEC positively affects evaluations of positive environmental impacts (PEI) but negatively affects evaluations of negative environmental impacts (NEI). PEC positively affects ES, while the relationship between PEC and NEI is moderated by PA.

Research limitations/implications. Items used to measure PEC, PEI, and NEI are not exhaustive. SET has its own limitations in explaining residents' ES, which we have attempted to attenuate by using ST.

Practical implications. Using environmental certification as a communication tool must demonstrate to residents how it reduces negative externalities, rather than focusing only on its positive community benefits. Less well educated residents had the lowest ES, suggesting the need to use social media to increase ES.

Originality/value. This study contributes to understandings of the perceptions of the benefits of event certification by residents, and how this affects their ES. PA moderates the relationship between PEC and NEI.
\end{abstract}


Keywords: Event support; event certification; environmental impacts; place attachment; certification benefits; World Expo 


\section{Introduction}

Effective management of large and small-scale events depends on residents' sensitivities to positive and negative impacts (Chi et al., 2018; Prayag et al., 2013). This understanding can also facilitate the design, development, and implementation of event policies that minimize negative impacts and maximize benefits for local communities (Prayag et al., 2013; Stylidis et al., 2014). Unsurprisingly, event impact studies using the triple bottom line assessment of economic, socio-cultural, and environmental impacts, abound in the literature (e.g., Al-Emadi et al., 2017; Olya and Gavilyan, 2017; Prayag et al., 2013). In particular, existing studies have examined the relationships between different types of event impacts, quality-of-life, and event support (Al-Emadi et al., 2017; Kaplanidou et al., 2013). For example, Kaplanidou et al. (2013) investigated the influence of social, political, economic, and psychological impacts of events on quality-of-life and event support. Al-Emadi et al. (2017) investigated the triple bottom line effects of event impact on factors such as quality-of-life, attitude toward the event, and event support. Although Kaplanidou et al. (2013) evaluated event support using a single item, they did not consider environmental impacts, whereas Al-Emadi et al. (2017) evaluated environmental impacts before the actual event. Neither study examined environmental certification as a determinant of resident attitudes and perceptions towards an event.

Assessments of resident perceptions have often prioritized the economic impacts of events over environmental impacts (Al-Emadi et al., 2017; Guizzardi et al., 2017; Prayag et al., 2013; Wang et al., 2019), and the economic gains from an event often occur at the expense of the environment and society (Getz and Page, 2016). Accordingly, pressure has increased from governments, residents, and event organizers such as the International Olympics Committee (IOC), to host more sustainable events (Collins et al., 
2009; Guizzardi et al., 2017). In recent years, different ways of evaluating an event's environmental sustainability (e.g., ecological footprint - Collins et al., 2009; 2012) and event greening (Mair and Jago, 2010) have been proposed, but these are often costly, and difficult to implement (Glasson and Therivel, 2013).

Existing studies have three notable limitations. First, despite event support being well-researched (see Kaplanidou et al., 2013; Ouyang et al., 2017; Prayag and Savalli, 2020; Schnitzer et al., 2021; Stylidis et al., 2014), resident-focused studies omit considerations of the influence of environmental certification on environmental impacts. To the best of our knowledge, only Guizzardi et al. (2017) evaluated how perceived certification and environmental impacts affected overall attitudes toward the Milan World Expo. They concluded that perceptions of environmental impacts can predict the benefits that residents associate with event certification. Based on signaling theory (ST), it is evident that certification provides a strong indication to consumers that an organization is committed to organizational practices and culture that enhance sustainable development and customer value creation (Sebhatu and Enquist, 2007).

Second, environmental impact measurement is often reduced to a few items, measuring different types of pollution and littering (see Al-Emadi et al., 2017; Olya and Gavilyan, 2017; Ouyang et al., 2017; Prayag et al., 2013; Prayag and Savalli, 2020), except in a study by Guizzardi et al. (2017) which assessed 11 different environmental impacts. In most studies, the effect of negative environmental impacts on resident support (or lack thereof) is generally negligible, due to validity issues and the types of indicators used to measure negative impacts (Gursoy et al., 2019). Third, residents can have mixed reactions to tourism, and given the limitations of social exchange theory (SET), place perceptions have been argued to affect evaluations of both event impact and support 
(Scarpi et al., 2019; Smith et al., 2017). However, the relationship between place attachment (PA), residents' perceptions of impacts, and support, is at best contradictory (Látková and Vogt, 2012; Olya and Gavilyan, 2017). While Silva et al. (2013) modeled PA as an outcome of perceptions of tourism impacts, others modeled it as an antecedent (Chi et al., 2018; Eusébio et al., 2018). However, strong attachment does not lead to increased resident sensitivity to negative tourism impacts. In addition, stronger negative perceptions of the impacts of tourism do not always reduce support. Thus, the influence of PA on event impacts remains to be determined.

Our study contributes to the event management literature in three ways. First, the study provides empirical evidence of residents' PEC affecting both perceptions of environmental impacts (PEI and NEI) and ES. This extends Guizzardi et al. 's (2017) study, linking environmental impacts to only one benefit of certification without assessing the subsequent effects on residents' ES. Second, by focusing on residents' perceptions of negative and positive event environmental impacts, we address the call by Gursoy et al. (2019) for a more wide-ranging evaluation of these impacts. Third, by testing how the relationship between PEC and environmental impacts is moderated by PA, we provide further evidence for the role of place perceptions in determining residents' supportive behaviors. As such, this study aimed to examine a model based on SET and ST, postulating that residents' perceptions of event certification, influence their perceptions of environmental impacts and ES. The model was tested on residents of Milan in relation to the 2015 World Expo. Thus, this was a pre-COVID-19 study, when mega-events were primarily face-to-face. The COVID-19 pandemic has created uncertainties for megaevents (Ludvigsen and Hayton, 2020), leading to the cancellation of the 2020 Olympic games and Euro 2020 (Parnell et al., 2020). Given that some mega-events are dominated 
by a single sport, while others include a variety of sports, the size and type of mega-event, will affect how future events are hosted, with various hybrid forms of event hosting emerging (Ludvigsen and Hayton, 2020). COVID-19 is also likely to affect the sensitivity of local residents to having a large influx of visitors in their neighborhood (Ludvigsen and Hayton, 2020).

\section{Literature Review}

\subsection{Signaling Theory (ST) and Social Exchange Theory (SET)}

Signaling theory explains the behavior that occurs when two parties (individuals or organizations) engage in a relationship in which there is information asymmetry, with one party seeking to communicate (signal) specific information to the other, to facilitate decision-making processes (Connelly et al., 2011). Hence, firms use certification (including environmental certification) to signal their commitment to a particular issue incorporated in the accreditation standards. From the certified organization's perspective, environmental certification can function as an important marketing tool to communicate hidden environmental commitments (i.e. practices) that are often difficult for consumers to observe and evaluate (D'Souza et al., 2019). Therefore, environmental certification can help reduce the information asymmetries inherent in the consumer-firm relationship concerning environmental commitments. From the consumer's perspective, certification provides assurance of an organization's commitment and compliance to international standards (Esparon et al., 2014). Thus, an environmentally certified event can signal to potential attendees, the event's commitment to reducing environmental impacts, thereby facilitating the decision to attend and support the event.

Social exchange theory is a prominent theoretical lens used to understand perceptions of residents on the impacts of tourism (Nunkoo and Ramkissoon, 2011; 
Prayag and Savalli, 2020; Schnitzer et al., 2021), green practices and consumers' perceived value in a hotel context (Assaker et al., 2020), and event support (Gursoy and Kendall, 2006; Gursoy et al., 2019; Prayag et al., 2013). SET assumes that individuals will participate in an exchange when they perceive that the benefits are greater than the costs (Assaker et al., 2020; Nunkoo and Ramkissoon, 2011), implying that residents are more likely to support an event when the perceived benefits accruing to them are greater than are the costs (Gursoy and Kendall, 2006; Gursoy et al., 2019). If the event is perceived to have many negative impacts, residents show reduced support (Gursoy et al., 2019; Prayag et al., 2013; Prayag and Savalli, 2020). However, SET has been criticized for over-simplifying the decision-making processes of residents, ignoring how place and context affect perceptions, and emphasizing rationality over affective responses (Ouyang et al., 2017). Incorporating PA in examining the effect of residents' support on tourism development can therefore improve the explanatory power of SET (Gursoy et al., 2019; Sung et al., 2021).

By integrating ST and SET, we postulate that an event organizer expects a signal (certification) to be perceived positively, and reciprocated in the form of ES, which is vital for the success of the event. Thus, both ST and SET explain the link between the signal and the response episode, with the signaling action of the event organizer having consequences on the response from residents. The response is determined by how residents evaluate the event's positive and negative environmental impacts. While ST emphasizes the role of certification as a means for stakeholders to evaluate the event's environmental commitment, SET explains the stakeholders' response in relationship building with the event, which will be in proportion to the perceived benefits they expect to accrue. 


\subsection{Event Environmental Impacts}

The Milan World Expo qualifies as a mega-event due to its size and impact on the local economy (Guizzardi et al., 2017). Mega-events affect the natural and built environments through positive and negative environmental impacts (Collins et al., 2009; Wang et al., 2019). In particular, they can lead to a revitalization of the host city, especially when sustainable initiatives are pilot tested before implementation (Collins et al., 2009). International organizations such as the IOC and Fédération Internationale de Football Association (FIFA), have stressed the importance of environmental considerations in event planning and staging. For example, the Beijing 2008 Olympic Games were used as a vehicle to promote environmental awareness among residents, through emphasizing a 'Green' Olympics and a commitment to 'zero-net emissions' by the organizing committee (Collins et al., 2009). Mega-events can also help to preserve the physical landscape and aspects of the local heritage that would otherwise be ignored (Chi et al., 2018; Ouyang et al., 2017). However, Al-Emadi et al. (2017) found that environmental impacts had no significant influence on resident support (i.e., Qataris and expatriates) before the Qatar FIFA World Cup in 2022.

Mega-events can also negatively impact local eco-systems, utilize reserves of irreplaceable natural capital, and increase carbon emissions that contribute to climate change (Collins et al., 2009; Wang et al., 2019). They can also change land use patterns and damage cultural and historical resources (Kim et al., 2006), while causing architectural pollution, over-tourism, and the development of non-sustainable event facilities (Preuss, 2009). Mega-events can also increase litter and pollution (e.g., noise, air and visual) (Chi et al., 2018; Prayag et al., 2013). However, quantifying the 
contribution of a mega-event to specific environmental issues (e.g., climate change and the use of non-renewable resources) is problematic (Wang et al., 2019). Existing environmental impact management initiatives are also not always successful. For example, the 'Green Goal 2010' program for the FIFA 2010 World Cup in South Africa was initially aimed at managing waste and recycling, improving biodiversity protection, upgrading public transport, and introducing energy efficiency measurements at stadiums. However, due to a lack of coordination, the program was implemented sporadically across the various hosting cities, leading to sub-optimal event outcomes and a missed opportunity to leave an environmental legacy for the host communities (Death, 2011).

\subsection{Environmental Certification and Events}

Studies on how consumers perceive event certification and its benefits are scarce (Getz and Page, 2016). As the first universal expo endowed with a certification, the Milan Expo 2015 complied with international standards on management systems for event sustainability (Guizzardi et al., 2017). However, there was poor awareness of this certification among Milan's residents, while those who were aware were unsure of its benefits (Guizzardi et al., 2017). Wang et al. (2019) found that environmental certification was absent from the governance structure of the 2011 International Horticultural Exposition in Xi'an, China, despite the implementation of several event greening processes and practices. Mega-events' greening practices can include pollution regulation, sustainable waste management, water conservation, recycling, biodiversity protection, and investments in greening the ecosystem (Wang et al., 2019). Generally, environmental certification schemes provide consumer benefits in the form of quality assurance (Esparon et al., 2014). Environmental certifications can also promote the voluntary adoption of sustainability practices, eliminate environmentally harmful 
practices, and attract eco-friendly customers, reducing costs and improving employees' knowledge of jobs and production systems (Geerts, 2014). These certifications can also facilitate better linkages with local communities, and increase public relations benefits (Rowe and Higham, 2007).

\section{Hypotheses Development}

\subsection{Perceptions of Environmental Certification (PEC) and Environmental Impacts}

Environmentally conscious individuals tend to exhibit behaviors that minimize their negative impacts on the natural environment, and implement actions that improve the environment (Cheng et al., 2013; Steg and Vlek, 2009), such as those that promote environmental protection (Steg and Vlek, 2009). An event that complies with environmental standards will be perceived by residents favorably when the perceived benefits of environmental certification contribute to reducing perceived environmental damage (Wang et al., 2019). Based on ST, the adoption of an environmental certification communicates an organizer's environmental protection commitment to stakeholders. Certification helps organizers build positive public opinion, market credibility, and customers' trust, by signaling that the event complies with stakeholders' expectations of environmental management (Buathong and Lai, 2017). Studies in tourism and hospitality have shown that various strategic actions implemented by organizations signaled their environmental commitments to stakeholders, such as the adoption of green practices or environmentally friendly services (Aboramadan and Karatepe, 2021; Balaji et al., 2019; Galeazzo et al., 2021; Manaktola and Jauhari, 2007). Events, however, face challenges in highlighting their environmental commitments and improvements, primarily due to the temporary and non-repetitive nature of some events. Consequently, customers and residents can find it difficult to make a priori assessments of an event's environmental 
sustainability. Thus, environmental certification can provide an effective means for signaling environmental commitments to gain customer attention and trust, while enhancing an event's reputation, both offline and online (Mariani and Borghi, 2021).

As customers and residents interpret the environmental certification signal positively, they will gain confidence in the event's environmental commitments in two ways. First, the perceived benefits of certification will contribute to reinforce their beliefs that the event's environmental certification provides tangible evidence of the positive community benefits. Second, the perceived benefits of environmental certification will contribute to mitigating perceptions of environmental damages from event hosting (Wang et al., 2019). Accordingly, we propose:

$\mathbf{H}_{1}$. PEC will have a positive effect on perceived positive environmental impacts (PEI)

$\mathbf{H}_{2}$. PEC will have a negative effect on perceived negative environmental impacts (NEI)

\subsection{PEI and ES}

Based on ST, certification signals that an event organizer is committed to managing environmental impacts. If residents perceive this signal positively, their trust and confidence in the event's environmental benefits for the community will improve, affecting their cognitive, affective, and behavioral responses. SET suggests that residents are willing to reciprocate with supportive behaviors when an event's positive impacts outweigh any negative impacts (Prayag et al., 2013), leading to the relationship between positive event impacts and resident support being well founded (Chi et al., 2018). For example, aggregating all positive event impacts (e.g., economic, social, and environmental), including raising environmental awareness, conservation, and protection, 
Chi et al. (2018) found a positive association between PEI and ES before and after the 2014 FIFA World Cup in Brazil. Prayag et al. (2013) found the same relationship for the 2012 London Olympics, but mediated by overall attitude. However, anecdotal evidence suggests this is not always the case. For example, Al-Emadi et al. (2017) found an insignificant relationship between PEI and ES for the upcoming 2022 Qatar FIFA World Cup. Thus, we propose:

H. PEI have a positive effect on ES

\subsection{NEI and ES}

Resident attitude studies have confirmed an inverse relationship between negative perceptions of the impacts of tourism, and support for tourism development (Eusébio et al., 2018; Nunkoo and Ramkissoon, 2010). However, residents can downgrade the importance of negative impacts when they perceive positive community benefits accruing from tourism development (Chen and Chen, 2010). Validity issues in the measurement of NEI can also affect its relationship with resident support (Gursoy et al., 2019). Thus, evidence on the effect of NEI on ES is contradictory. For example, Al-Emadi et al. (2017) could not confirm this relationship among residents in relation to the planned 2022 Qatar FIFA World Cup. Aggregating all negative impacts (including environmental ones), the negative effect on ES has been confirmed in previous studies (Chi et al., 2018; Ouyang et al., 2017). Prayag et al. (2013) showed that the relationship between NEI and ES was fully mediated by overall attitude. Thus, we propose:

$\mathbf{H}_{4}$. NEI have a negative effect on ES

\subsection{PEC and ES}


Consumers' positive attitudes and behaviors toward environmentally certified products and services have been noted (Martínez et al., 2019; Sharma et al., 2020). Arguably, an interest in environmental issues and awareness of the benefits of environmental certification should influence consumer purchasing behavior (Sharma et al., 2020). An event organizer's environmental certification signals to local residents and event participants, its commitment to managing environmental impacts (Wang et al., 2019). Based on ST, we argue that this signal is received positively by residents because they transfer existing knowledge on the benefits of certification from their previous experiences with consumer products, and use this to evaluate the credibility of the signal (benefits), which then informs their support of the event. Wang et al. (2019) argued that compliance with environmental standards by event organizers can improve the environmental practices of mega-events, but whether this affects residents' perceptions of and support for an event, was not evaluated. Thus, an event that is perceived as complying with environmental standards, is likely to have greater support from residents. Thus, we propose:

\section{H5. PEC will have a positive effect on ES}

\subsection{The Moderating Role of PA}

The effects of environmental benefits signaled to residents by certification in terms of positive and negative environmental benefits have been objectively examined in the previous sections. It is important to note, however, that how the signal is received is conditional on several factors, including the receiver's characteristics (Cheung et al., 2014), and how they align with ST; such conditional factors will moderate the relationship between the signal and how it is received (Cheung et al., 2014). Thus, we argue that residents' characteristics in relation to place perceptions, will moderate the relationship 
between their perceptions of certification and perceived event impacts (positive and negative). From a behavioral perspective, these relationships will be different for residents who have stayed in a place longer than those who have not. Among the different conditional factors related to resident characteristics, we consider that their PA levels play a significant role in influencing their perceptions of the potential environmental benefits of certification.

Place attachment (PA) can be defined as people's attachment to and the meanings ascribed to physical place (Lee et al., 2012). The concept is multi-dimensional, consisting of place identity, place dependence, and social bonding (Lee et al., 2012; Ramkissoon and Mavondo, 2015), but study results have often shown that place identity is indistinguishable from social bonding (Lee et al., 2012). Unsurprisingly, several studies have considered PA as a unidimensional construct (Eusébio et al., 2018). While several studies have examined the influence of PA on pro-environmental behaviors (Cheng et al., 2013; Cheng and Wu, 2015) and events (Oshimi and Harada, 2019; Scarpi et al., 2019), there is no consensus on whether PA affects perceived tourism or event impacts. For example, Tournois and Djeric (2019) failed to identify any moderating effects of PA on the relationship between perceived impacts (economic, socio-cultural, and environmental) and support for tourism development. Wang and $\mathrm{Xu}$ (2015) demonstrated the direct effect of place identity on attitudes to the positive and negative impacts of tourism. In the events literature, researchers have focused on related concepts such as community attachment (Gursoy and Kendall, 2006), event attachment (Ouyang et al., 2017) and venue attachment (Smith et al., 2017), because they affect how an event is perceived, and the subsequent support for it. Ouyang et al. (2017), for example, found that event attachment moderates the relationship between trust and perceived positive and 
negative event impacts. Others have shown the moderating role of PA on quality judgements and behavioral outcomes (Kim et al., 2017).

Residents' PA depends on identification with, dependence on, and embeddedness of, social relationships within a community (Chen et al., 2021). Stronger PA generates more positive attitudes toward a place, and a stronger sense of self in relation to place (Raggiotto and Scarpi, 2021). Thus, residents with strong PA, are likely to have a strong interest in environmental issues that affect a place (Halpenny, 2010; Ramkissoon et al., 2012). While negative event impacts can be perceived as diminishing place environmental quality, environmental certification can counteract such perceptions by highlighting environmental benefits among residents with strong PA. Certification serves as a proxy to residents that PEI will occur and make their neighborhood a better place to live. This expectation will lead to stronger identification with their place, and social bonding. To the contrary, an event perceived as producing negative outcomes for the environment, will not necessarily diminish PA among those who are highly attached, so long as they perceive that event certification will limit the negative environmental impacts. Thus, we suggest:

\section{$\mathbf{H}_{\mathbf{6 a}} \cdot$ PEC and PEI is positively moderated by $P A$ \\ $\mathbf{H}_{\mathbf{6} \mathbf{b}} \cdot$ PEC and NEI is positively moderated by PA}

Figure 1 encapsulates the six hypotheses of this study.

[Figure 1 here]

\section{Method}

\subsection{Study Context - The World Expo 2015}


Milan World Expo 2015 was the fourth World Expo held in Italy, and the second event hosted in Milan. As a periodic event, the theme of "Feeding the planet, energy for life," was one of the most controversial to date, due to the event's escalating budget and allegations of the organizers' corruption. The expo attracted participants from more than 200 countries, along with 20 million visitors (Ministero_Dell'Ambiente, 2015). One ambitious event objective was to show leadership in environmental issues, by being the first sustainable and carbon neutral expo. The expo was a field experiment that defined and tested tools, indicators, and initiatives, that aimed to minimize the event's environmental footprint. At the time of writing, it was the only World Expo endowed with an environmental certification, and would remain so until the following one in Dubai, in late 2021. World Expo 2015 adopted the ISO 20121 standard as the management system for event sustainability. Such adoption by organizers provides the appropriate context for evaluating residents' perceptions of certification and its environmental impacts. However, residents are not expected to understand ISO standards in their evaluation of the event's environmental impacts, but instead, we focused on whether certification as a marketing tool (D'Souza et al., 2009) was perceived to have positive benefits.

\subsection{Questionnaire Development}

Residents' PEC was measured using six items adapted from previous studies (Guizzardi et al., 2017; United Nations Environment Programme, 2012). PEI and NEI were operationalized using five and six modified items respectively, from former studies (Guizzardi et al., 2017; Prayag et al., 2013). ES was operationalized using three items adapted from Prayag et al. (2013) and Zhou and Ap (2009). Six items were used to measure PA based on previous studies (Lee et al., 2012; Prayag and Ryan, 2012; 
Ramkissoon and Mavondo, 2015). All constructs were measured on a 5-point Likert scale. The questionnaire's original language was English, which was then translated into Italian, and back-translated to ensure equivalence with the original questionnaire (Brislin, 1970). The questionnaire was pre-tested on a sample of Milan residents, leading to minor changes in item wording in the final version. To address common method bias (CMB) concerns, Harman's one-factor test using the 26 items used in the model was carried out (Podsakoff et al., 2003). No single factor explained more than $25.73 \%$ of the observed variance, suggesting that $\mathrm{CMB}$ was not a pervasive issue in the study.

\subsection{Sampling, Data Collection and Analysis}

Milan residents were the target population, and identified using a convenience sampling method as per previous studies (Gursoy and Kendall, 2006; Lorde et al., 2011). We selected respondents using two screening questions: first, are you a resident of Milan, and second, did you know that the World Expo 2015 is taking place in Milan? We collected data from March to July 2015 using a well-established market research company that is ISO 9001 certified for market and social research. With 35 employees, this company provides a range of market research services to private, governmental, and academic institutions in Europe. The company employed trained researchers to identify respondents using the specified screening criteria. Potential respondents were identified around public places in all nine neighborhoods of Milan, to capture a diverse socio-demographic profile, taking gender and age into account, so the sample could reflect some characteristics of the wider Milan population. In total, we obtained 450 useable completed questionnaires. We present the respondents' profile in Table 1.

\section{[Table 1 here]}


The sample size was estimated following established recommendations (Hair et al., (2017). Using a statistical power of $80 \%$, significance level of $5 \%$, and minimum $\mathrm{R}^{2}$ value of 0.10 , the recommended sample size was calculated as 174 , as indicated by the eight arrows pointing toward ES (see Figure 2). This is much smaller than the actual sample size of 450. We used SmartPLS 3.2.8 to analyze the data.

\section{Findings}

\subsection{Evaluation of Measurement Model}

Scale validity and reliability assessment are key to measurement model evaluation (Hair et al., 2017). Scale reliability was assessed using Cronbach's alpha ( $\alpha$ ), composite reliability (CR) and rho_A with a threshold of 0.70 , to establish internal consistency (Hair et al., 2017). After deleting four items (two items for NEI, one item for PEI, and one item for PA) due to low item loading $(<0.50)$, all remaining item loadings on their corresponding latent variables were higher than 0.70 , except for four indicators (see Table 2). These four indicators had item loadings ranging from 0.525 to 0.690 , suggesting that they should not be removed, as they did not affect the internal consistency reliability and average variance extracted (AVE) (Hair et al., 2017) of their respective constructs. Table 2 shows that internal consistency reliability of all reflective latent variables using all three coefficients (i.e. $\alpha$, CR and rho_A) were upheld. Results also showed that the AVEs of all latent variables were higher than the threshold value of 0.5 . Convergent validity of each reflective latent variable was assessed using Fornell and Larcker's (1981) criterion of AVE being higher than 0.50 (Hair et al., 2017). Table 2 shows that the AVE for all constructs ranged from 0.541 to 0.748 , thus exceeding the acceptable threshold.

\section{[Table 2 here]}


Discriminant validity was tested using two different methods. In the first method, we required all correlations be less than the square root of the AVE (Fornell and Larcker, 1981). Table 3 shows that this was met. In our second approach, we estimated that the Heterotrait-Monotrait (HTMT) correlation ratios should be less than 0.85, hence, discriminating the two factors (Henseler et al., 2016). Table 3 shows that all the correlation ratios were below the critical level. We assessed model fit using the standardized root mean square residual (SRMR), resulting in a value of 0.055 , which was less than 0.08 (Hu and Bentler, 1999), showing adequate fit for PLS path modeling (Henseler et al., 2016).

\section{[Table 3 here]}

\subsection{Structural Model Evaluation}

The structural model was assessed based on the step-by-step procedure recommended by Hair et al.(2017). First, we assessed multi-collinearity based on inner VIF values; these were less than the threshold of 5. Second, we assessed the path coefficient $(\beta)$ of all hypothesized paths. Our results showed that resident's PEC had a positive effect on PEI $(\beta=0.491, t=12.886, p<0.001)$, and a negative effect on NEI $(\beta=-0.217, t=3.942, p<0.001)$, supporting $\mathrm{H}_{1}$ and $\mathrm{H}_{2}$ respectively. PEI positively influenced $\mathrm{ES}(\beta=0.382, t=8.322$, $p<0.001)$, and NEI negatively influenced ES $(\beta=-0.258, t=5.995, p<0.001)$, providing support for $\mathrm{H}_{3}$ and $\mathrm{H}_{4}$ respectively. PEC positively influenced $\mathrm{ES}(\beta=0.186, t=4.287$, $p<0.001$ ), supporting $\mathrm{H}_{5}$. Our results revealed the positive moderating effect of PA on the relationship between PEC and NEI $(\beta=0.095, t=.988, p<0.05)$, but PA had no moderating effect on the relationship between PEC and PEI. This result suggests that higher levels of attachment to the city of Milan by residents, had attenuated the negative relationship 
between PEC and NEI. Therefore, the results supported $\mathrm{H}_{6 \mathrm{~b}}$ but not $\mathrm{H}_{6 \mathrm{a}}$. We also tested the total indirect effect of PEC on ES $(\beta=0.244, t=7.866, p<0.001)$; this indirect effect was stronger than was the direct effect. In the third step, we evaluated the model's predictive power using $R^{2}$ value; our model explained $10.1 \%$ and $30 \%$ of the variance in NEI and PEI respectively. The model also explained $44.5 \%$ of the variance in ES. In the next step, we assessed the effect size using the $\mathrm{f}^{2}$ value to examine the impact of independent variables on the dependent variables. The results indicated two medium size effects (i.e. $\mathrm{f}^{2}>0.15$ but $<0.35$ ), three small effects (i.e. $\mathrm{f}^{2}>0.02$ but $<0.15$ ), and a further two with effects smaller than 0.02 (see Table 4). In the last step, we examined Stone-Geisser's $\mathrm{Q}^{2}$ value to assess the model's predictive relevance; all $\mathrm{Q}^{2}$ values were greater than 0 , implying the predictive relevance of the exogenous variables on the endogenous constructs.

\section{[Table 4 here]}

We controlled for the effects of gender, age, education level, occupation, and the distance residents lived from the expo, on ES (see Figure 2). These variables had affected resident support for events and tourism development in previous studies (Prayag et al., 2013; Scarpi et al., 2019; Tournois and Djeric, 2019). None of these control variables had any significant effect on ES [e.g., gender $(\beta=0.036, t=0.975, p=0.330)$, age $(\beta=0.001$, $t=0.0 .20, p=0.984)$, occupation $(\beta=0.018, t=0.483, p=0.629)$, distance to expo $(\beta=-0.024$, $t=0.747, p=0.455)]$ except for education level. Education level positively affected $(\beta=0.133, t=3.448, p<0.001) \mathrm{ES}$, suggesting that the better educated respondents had stronger ES. The distance that residents lived from the expo had no significant effect on PEI and NEI, but respondents' occupation had a negative and significant effect on NEI $(\beta=-0.100, t=2.044, p<0.05)$, but no significant effect on PEI $(\beta=-0.073, t=1.800$, 
$p=0.072$ ). As an additional test, we assessed the influence of residents' education level on PEC, which resulted in a non-significant effect ( $\mathrm{p}>0.05)$. This implies that residents' formal education had little to do with their understanding of the benefits of environmental certification.

\section{[Figure 2 here]}

\section{Discussion and Conclusion}

\subsection{Discussion}

This study evaluated a theoretical model based on ST and SET, postulating that residents' perceptions of event environmental certification affected their evaluations of environmental impacts and ES. Place attachment was purported to have a moderating effect on the relationship between event certification and environmental impacts. The findings highlight the importance of certification in shaping residents' support for an event. Perceptions of the event's NEI affected residents' PA by modifying place identity, dependence, and social bonding. Thus, the attitudes and perceptions of residents towards their own community are impacted by mega-events, having implications for long-term quality-of-life and wellbeing (Kaplanidou et al., 2013). Event organizers need to consider the legacy for communities in relation to PA, in that events should strengthen PA and build social capital by strengthening community relationships.

\subsection{Theoretical Implications}

Similar to the findings of previous studies (Gursoy and Kendall, 2006; Gursoy et al., 2019; Nunkoo and Ramkissoon, 2011; Prayag et al., 2013; Prayag and Savalli, 2020; Schnitzer et al., 2021), we confirmed SET as a useful framework for understanding residents' perceptions of environmental impacts and their subsequent ES. By 
incorporating ST in the conceptual model, we extended SET and showed that residents perceive certification as a positive indicator of the environmental benefits of an event. Accordingly, residents expect the benefits of certification will improve an event's PEI while reducing NEI, as suggested in $\mathrm{H}_{1}$ and $\mathrm{H}_{2}$ respectively. The positive benefits of certification can reduce information asymmetry between event organizers and residents, allowing the latter to use certification as a proxy for assessing the environmental impacts of an event. This finding concurs with those of Guizzardi et al.(2017), but we extended the range of benefits associated with certification by residents. Wang et al. (2019) suggested that compliance with environmental standards can create positive environmental benefits for event organizers. We extended this by showing that the positive benefits of certification by residents contribute to their perceptions that an event has higher PEI, but lower NEI.

When perceptions of environmental impacts are positive, residents increase ES, as suggested by $\mathrm{H}_{3}$. This finding concurs with Prayag et al.'s (2013) call for the disaggregation of event positive impacts, using the triple bottom line approach to improve understandings of environmental impacts. Likewise, the more NEI residents perceive, the lower is their ES, as suggested by $\mathrm{H}_{4}$. While this finding mirrors the results of previous event studies (Chi et al., 2018; Ouyang et al., 2017) that aggregated the triple bottom line impacts, our findings highlight that NEI on their own have a direct influence on ES, providing contrary evidence to that of existing studies (Al-Emadi et al., 2017; Prayag et $a l ., 2013)$. Perceptions of event certification benefits can improve ES by residents as suggested by $\mathrm{H}_{5}$, establishing the former as an important antecedent of the latter. Thus, beyond overall attitudes towards an event, which were determined by perceptions of environmental impacts in Guizzardi et al. 's (2017) work, certification influences a range 
of supportive behaviors from residents. This finding also extends into the hospitality field (Martínez et al., 2019), where the focus has been on the relationship between hotel choice, certification (Sharma et al., 2020), and environmental practices (González-Rodríguez et al., 2020). A greater focus on measuring the effectiveness of green certification schemes is required throughout both hospitality and events fields (Sharma et al., 2020).

Attachment can improve the explanatory power of SET for resident support models of tourism development (Gursoy et al., 2019). Similar to other authors (Scarpi et al., 2019; Smith et al., 2017), we argue that perceptions of place have an effect on residents' evaluations of event impacts. However, unlike previous studies (Chi et al., 2018; Eusébio et al., 2018; Silva et al., 2013), this study showed the moderating effect of PA on SET-based ES models, rather than direct or mediating effects. Extending the work of Tournois and Djeric (2019) on tourism development, we showed that PA has a moderating effect on perceptions of event impacts. PA is equally relevant to event studies that primarily assessed the influence of concepts such as community and event attachment on ES (Sung et al., 2021).

As a moderator, PA attenuates the relationship between PEC and NEI, as suggested by $\mathrm{H}_{6 \mathrm{~b}}$, but not for PEI $\left(\mathrm{H}_{6 \mathrm{a}}\right)$. This implies that certification provides the right signal to residents that event organizers will manage negative impacts effectively. Thus, residents who are more attached to place, expect that an event's environmental certification will be used to reduce the NEI on the community. In this way, the relationship between PA, event impacts, and certification, highlights the importance of sustainable events to communities. Related concepts such as event (Ouyang et al., 2017; Sung et al., 2021), venue (Smith et al., 2017) and community attachment (Gursoy and Kendall, 2006), are important in relation to the finding of this study, by showing how PA 
develops and is strengthened, by managing event impacts in such a way that the benefits to communities outweigh the costs. This is a central tenet of SET. However, the result of $\mathrm{H}_{6 \mathrm{a}}$ did not support the idea that residents who are more place attached, expect that an event's environmental certification will magnify the positive environmental benefits for the community. A plausible explanation for this could be that during the event studied, residents were more concerned, or experienced more negative environmental impacts than positive ones. As suggested by Guizzardi et al. (2017), residents of Milan had poor knowledge of the certification, and poor awareness of environmental impacts prior to the event. These concerns became more significant during the event, when negative impacts were felt on the community, as suggested by the results.

\subsection{Managerial Implications}

The results suggest that residents have positive PEC when they limit various types of pollution (e.g., air, noise, and visual), litter, and traffic congestion. In essence, certification should limit environmental damage, as professed by the organizing committee of the Milan World Expo. However, ES is dampened by residents' perceptions of NEI, as suggested by the findings. Event organizers should therefore better communicate environmental sustainability achievements both during and after the event, as shown in past studies (Guizzardi et al., 2017). The indirect effect of PEC on ES is stronger through NEI than through PEI, suggesting that using certification as a marketing tool must demonstrate the reduced negative impacts, and not just focus on positive benefits for the community. Information provision campaigns for boosting ES should focus on residents with poor education levels, as they have the weakest ES, according to the findings. As occupation had a significant effect on perceptions of NEI in this study, we advise that marketing campaigns should be customized to highlight (for example) to 
retirees, that the event is managing NEI on the community through its certification standards.

Marketing campaigns to gain ES from residents should also consider their attachment levels to the city. Through community surveys, the extent of residents' identification with place (place identity), dependence on the existing infrastructure and amenities (place dependence), and the depth of their social networks and relationships (social bonding) can be assessed (Chen et al., 2021) to better understand their support for the event. Place identification and social bonding can be developed and strengthened through regular community events, thus building social capital. As the findings suggest, residents who are strongly attached to their city, are more sensitive to a certification being used to minimize an event's NEI. Residents' attachment levels can be used to design ES communication campaigns, having implications for the media mix used to deliver campaigns to different resident groups. Poorly educated residents could be targeted using social media rather than print media. However, post-pandemic marketing campaigns to boost residents' support for events will have to mitigate the existing fear and safety concerns of COVID-19 spreading as a result of hosting an event (Ludvigsen and Hayton, 2020). Understanding residents' engagement with environmental issues on social media may also provide a way to understand the importance of managing environmental impacts to boost ES, and guide decisions for event attendance. As Mariani and Borghi (2021) observed, online consumers' environmental discourses positively affect how they perceive electronic word-of-mouth helpfulness in hotel choice.

In terms of policy implications, event sustainability certification provides a comprehensive assessment of an event's environmental impacts, from event bidding and preparation (pre-event), to execution and the aftermath (post-event). Understandably, 
mega-events can offer significant economic and social benefits for communities. However, such benefits need to be balanced against the likelihood that negative environmental impacts may linger after the event, and hence compromise the long-term community benefits. Governments therefore need to develop event policies that will lead to positive net benefits (both short-term and long-term), by incorporating inputs from community members that are directly and indirectly (i.e., neighborhood or sheer proximity) impacted by the event. Furthermore, while mandating event certification might still be in the distant future, governments can incentivize certified events and help promote them in the community, and most importantly, educate the community on the environmental benefits of the event, as well as on strategies to mitigate the environmental costs. Incentives can also be provided to companies that supply products and services to event organizers, so that supply chain practices are green. When green initiatives are used in organizations, they increase employee performance and organizational citizenship behaviors (Aboramadan and Karatepe, 2021).

\subsection{Limitations and Future Research}

Four major limitations of this study were identified. First, the items used to measure the benefits of event certification and environmental impacts are not exhaustive. Future studies can expand these by incorporating other facets of certification such as energy use, water, and waste management. A more comprehensive assessment of environmental impacts using better measurement items is necessary.(Gursoy et al., 2019). Second, data collected during an event can increase residents' sensitivity to its impacts, affecting evaluations of PEI and NEI. Future studies can attenuate this sensitivity by comparing pre, during, and post event data. Third, SET has its own limitations (see Ouyang et al., 2017), which we attenuated through its integration with ST. However, other theories such 
as social dilemma theory (Chien et al., 2012) alongside ST may also be relevant in explaining residents' ES. Fourth, this was a pre COVID-19 study, when face-to-face events and data collections were the norm. However, some mega-events such as the 2021 Olympic Games, were hosted mainly for a virtual audience, whereas the 2021 World Expo in Dubai was maintained as a face-to-face event; future studies should therefore examine support for mega-events that are either fully online or hybrid versions.

\section{References}

Aboramadan, M. \& Karatepe, O.M., (2021). "Green human resource management, perceived green organizational support and their effects on hotel employees' behavioral outcomes", International Journal of Contemporary Hospitality Management, Vol. 33 No. 10, pp. 3199-3222.

Al-Emadi, A., Kaplanidou, K., Diop, A., Sagas, M., Le, K. \& Al-Ali Mustafa, S., (2017). "2022 Qatar world cup: impact perceptions among Qatar residents", Journal of Travel Research, Vol. 56 No. 5, pp. 678-694.

Assaker, G., Hallak, R. \& O'connor, P., (2020). "Examining heterogeneity through response-based unit segmentation in PLS-SEM: a study of human capital and firm performance in upscale restaurants", Current Issues in Tourism, Vol. 23 No. 2, pp. 137-152.

Balaji, M., Jiang, Y. \& Jha, S., (2019). "Green hotel adoption: a personal choice or social pressure?", International Journal of Contemporary Hospitality Management, Vol. 31 No. 8, pp. 3287-3305.

Brislin, R.W., (1970). "Back-translation for cross-cultural research", Journal of CrossCultural Psychology, Vol. 1 No. 3, pp. 185-216.

Buathong, K. \& Lai, P.-C., (2017). "Perceived attributes of event sustainability in the MICE industry in Thailand: a viewpoint from governmental, academic, venue and practitioner", Sustainability, Vol. 9 No. 7, pp. 1151.

Chen, C.-F. \& Chen, F.-S., (2010). "Experience quality, perceived value, satisfaction and behavioral intentions for heritage tourists", Tourism Management, Vol. 31 No. 1, pp. 29-35.

Chen, N.C., Hall, C.M. \& Prayag, G., (2021). Sense of place and place attachment in tourism, 1st ed. Routledge: New York.

Cheng, T.-M., C. Wu, H. \& Huang, L.-M., (2013). "The influence of place attachment on the relationship between destination attractiveness and environmentally responsible behavior for island tourism in Penghu, Taiwan", Journal of Sustainable Tourism, Vol. 21 No. 8, pp. 1166-1187.

Cheng, T.-M. \& Wu, H.C., (2015). "How do environmental knowledge, environmental sensitivity, and place attachment affect environmentally responsible behavior? An integrated approach for sustainable island tourism", Journal of Sustainable Tourism, Vol. 23 No. 4, pp. 557-576. 
Cheung, C.M., Xiao, B.S. \& Liu, I.L., (2014). "Do actions speak louder than voices? The signaling role of social information cues in influencing consumer purchase decisions", Decision Support Systems, Vol. 65, pp. 50-58.

Chi, C.G.-Q., Ouyang, Z. \& Xu, X., (2018). "Changing perceptions and reasoning process: comparison of residents' pre-and post-event attitudes", Annals of Tourism Research, Vol. 70, pp. 39-53.

Chien, P.M., Ritchie, B.W., Shipway, R. \& Henderson, H., (2012). "I am having a dilemma: factors affecting resident support of event development in the community", Journal of Travel Research, Vol. 51 No. 4, pp. 451-463.

Collins, A., Jones, C. \& Munday, M., (2009). "Assessing the environmental impacts of mega sporting events: two options?", Tourism Management, Vol. 30 No. 6, pp. 828-837.

Collins, A., Munday, M. \& Roberts, A., (2012). "Environmental consequences of tourism consumption at major events: an analysis of the UK stages of the 2007 Tour de France", Journal of Travel Research, Vol. 51 No. 5, pp. 577-590.

Connelly, B.L., Certo, S.T., Ireland, R.D. \& Reutzel, C.R., (2011). "Signaling theory: a review and assessment", Journal of Management, Vol. 37 No. 1, pp. 39-67.

D’souza, C., Marjoribanks, T., Young, S., Sullivan Mort, G., Nanere, M. \& John, J.J., (2019). "Environmental management systems: an alternative marketing strategy for sustainability", Journal of Strategic Marketing, Vol. 27 No. 5, pp. 417-434.

Death, C., (2011). "'Greening'the 2010 FIFA World Cup: environmental sustainability and the mega-event in South Africa", Journal of Environmental Policy \& Planning, Vol. 13 No. 2, pp. 99-117.

Esparon, M., Gyuris, E. \& Stoeckl, N., (2014). "Does ECO certification deliver benefits? An empirical investigation of visitors' perceptions of the importance of ECO certification's attributes and of operators' performance", Journal of Sustainable Tourism, Vol. 22 No. 1, pp. 148-169.

Eusébio, C., Vieira, A.L. \& Lima, S., (2018). "Place attachment, host-tourist interactions, and residents' attitudes towards tourism development: the case of Boa Vista Island in Cape Verde", Journal of Sustainable Tourism, Vol. 26 No. 6, pp. 890-909.

Fornell, C. \& Larcker, D.F., (1981). "Evaluating structural equation models with unobservable variables and measurement error", Journal of Marketing Research, Vol. 18 No. 1, pp. 39-50.

Galeazzo, A., Ortiz-De-Mandojana, N. \& Delgado-Ceballos, J., (2021). "Green procurement and financial performance in the tourism industry: the moderating role of tourists' green purchasing behaviour", Current Issues in Tourism, Vol. 24 No. 5, pp. 700-716.

Geerts, W., (2014). "Environmental certification schemes: hotel managers' views and perceptions", International Journal of Hospitality Management, Vol. 39, pp. 8796.

Getz, D. \& Page, S.J., (2016). "Progress and prospects for event tourism research", Tourism Management, Vol. 52, pp. 593-631.

Glasson, J. \& Therivel, R., (2013). Introduction to environmental impact assessment Routledge: London.

González-Rodríguez, M.R., Díaz-Fernández, M.C. \& Font, X., (2020). "Factors influencing willingness of customers of environmentally friendly hotels to pay a 
price premium", International Journal of Contemporary Hospitality Management, Vol. 32 No. 1, pp. 60-80.

Guizzardi, A., Mariani, M. \& Prayag, G., (2017). "Environmental impacts and certification: evidence from the Milan World Expo 2015", International Journal of Contemporary Hospitality Management, Vol. 29 No. 3, pp. 1052-1071.

Gursoy, D. \& Kendall, K., (2006). "Hosting mega events: modeling locals' support", Annals of Tourism Research, Vol. 33 No. 3, pp. 603-623.

Gursoy, D., Ouyang, Z., Nunkoo, R. \& Wei, W., (2019). "Residents' impact perceptions of and attitudes towards tourism development: a meta-analysis", Journal of Hospitality Marketing \& Management, Vol. 28 No. 3, pp. 306-333.

Hair, J.F., Hult, G.T.M., Ringle, C.M. \& Sarstedt, M., (2017). A Primer on partial least square structural equation modelling (PLS-SEM), 2nd ed. SAGE Publications: Thousand Oaks, California.

Halpenny, E.A., (2010). "Pro-environmental behaviours and park visitors: the effect of place attachment", Journal of Environmental Psychology, Vol. 30 No. 4, pp. 409-421.

Henseler, J., Hubona, G. \& Ray, P.A., (2016). "Using PLS path modeling in new technology research: updated guidelines", Industrial Management \& Data Systems, Vol. 116 No. 1, pp. 2-20.

Hu, L.-T. \& Bentler, P.M., (1999). "Cutoff criteria for fit indexes in covariance structure analysis: conventional criteria versus new alternatives", Structural Equation Modeling, Vol. 6 No. 1, pp. 1-55.

Kaplanidou, K., Karadakis, K., Gibson, H., Thapa, B., Walker, M., Geldenhuys, S. \& Coetzee, W., (2013). "Quality of life, event impacts, and mega-event support among South African residents before and after the 2010 FIFA World Cup", Journal of Travel Research, Vol. 52 No. 5, pp. 631-645.

Kim, H.J., Gursoy, D. \& Lee, S.-B., (2006). "The impact of the 2002 World Cup on South Korea: comparisons of pre-and post-games", Tourism Management, Vol. 27 No. 1, pp. 86-96.

Kim, S., Lee, Y.-K. \& Lee, C.-K., (2017). "The moderating effect of place attachment on the relationship between festival quality and behavioral intentions", Asia Pacific Journal of Tourism Research, Vol. 22 No. 1, pp. 49-63.

Látková, P. \& Vogt, C.A., (2012). "Residents' attitudes toward existing and future tourism development in rural communities", Journal of Travel Research, Vol. 51 No. 1, pp. 50-67.

Lee, J., Kyle, G. \& Scott, D., (2012). "The mediating effect of place attachment on the relationship between festival satisfaction and loyalty to the festival hosting destination", Journal of Travel Research, Vol. 51 No. 6, pp. 754-767.

Lorde, T., Greenidge, D. \& Devonish, D., (2011). "Local residents' perceptions of the impacts of the ICC Cricket World Cup 2007 on Barbados: comparisons of preand post-games", Tourism Management, Vol. 32 No. 2, pp. 349-356.

Ludvigsen, J.a.L. \& Hayton, J.W., (2020). "Toward COVID-19 secure events: considerations for organizing the safe resumption of major sporting events", Managing Sport and Leisure, pp. 1-11. https://doi.org/10.1080/23750472.2020.1782252

Mair, J. \& Jago, L., (2010). "The development of a conceptual model of greening in the business events tourism sector", Journal of Sustainable Tourism, Vol. 18 No. 1, pp. 77-94. 
Manaktola, K. \& Jauhari, V., (2007). "Exploring consumer attitude and behaviour towards green practices in the lodging industry in India", International Journal of Contemporary Hospitality Management, Vol. 19 No. 5, pp. 364-377.

Mariani, M. \& Borghi, M., (2021). "Are environmental-related online reviews more helpful? A big data analytics approach", International Journal of Contemporary Hospitality Management, Vol. 33 No. 6, pp. 2065-2090.

Martínez, P., Herrero, Á. \& Gómez-López, R., (2019). "Corporate images and customer behavioral intentions in an environmentally certified context: promoting environmental sustainability in the hospitality industry", Corporate Social Responsibility and Environmental Management, Vol. 26 No. 6, pp. 1382-1391.

Ministero_Dell'ambiente, (2015). The expo we learned: the legacy of a mega-event in a circular economy perspective. Italian Ministry for Envrionment, Land and Sea: Rome, Italy.

Nunkoo, R. \& Ramkissoon, H., (2010). "Small island urban tourism: a residents' perspective", Current Issues in Tourism, Vol. 13 No. 1, pp. 37-60.

Nunkoo, R. \& Ramkissoon, H., (2011). "Developing a community support model for tourism", Annals of Tourism Research, Vol. 38 No. 3, pp. 964-988.

Olya, H.G. \& Gavilyan, Y., (2017). "Configurational models to predict residents' support for tourism development", Journal of Travel Research, Vol. 56 No. 7, pp. 893-912.

Oshimi, D. \& Harada, M., (2019). "Host residents' role in sporting events: the city image perspective", Sport Management Review, Vol. 22 No. 2, pp. 263-275.

Ouyang, Z., Gursoy, D. \& Sharma, B., (2017). "Role of trust, emotions and event attachment on residents' attitudes toward tourism", Tourism Management, Vol. 63, pp. 426-438.

Parnell, D., Widdop, P., Bond, A. \& Wilson, R., (2020). "COVID-19, networks and sport", Managing Sport and Leisure,pp. 1-7. https://doi.org/10.1080/23750472.2020.1750100

Podsakoff, P.M., Mackenzie, S.B., Lee, J.Y. \& Podsakoff, N.P., (2003). "Common method biases in behavioral research: a critical review of the literature and recommended remedies", Journal of Applied Psychology, Vol. 88 No. 5, pp. 879-903.

Prayag, G., Hosany, S., Nunkoo, R. \& Alders, T., (2013). "London residents' support for the 2012 Olympic Games: the mediating effect of overall attitude", Tourism Management, Vol. 36, pp. 629-640.

Prayag, G. \& Ryan, C., (2012). "Antecedents of tourists' loyalty to Mauritius: the role and influence of destination image, place attachment, personal involvement, and satisfaction", Journal of Travel Research, Vol. 51 No. 3, pp. 342-356.

Prayag, G. \& Savalli, M., (2020). Residents' perceptions of event impacts and support for the 2012 Formula One Grand Prix in Monaco. In D. Gursoy, R. Nunkoo \& M. Yolal (eds.) Festival and event tourism impacts. Routledge, 139-153.

Preuss, H., (2009). "Opportunity costs and efficiency of investments in mega sport events", Journal of Policy Research in Tourism, Leisure and Events, Vol. 1 No. 2, pp. 131-140.

Raggiotto, F. \& Scarpi, D., (2021). "This must be the place: a destination-loyalty model for extreme sporting events", Tourism Management, Vol. 83, pp. 104254. 
Ramkissoon, H. \& Mavondo, F.T., (2015). "The satisfaction-place attachment relationship: potential mediators and moderators", Journal of Business Research, Vol. 68 No. 12, pp. 2593-2602.

Ramkissoon, H., Weiler, B. \& Smith, L.D.G., (2012). "Place attachment and proenvironmental behaviour in national parks: the development of a conceptual framework", Journal of Sustainable Tourism, Vol. 20 No. 2, pp. 257-276.

Rowe, T. \& Higham, J., (2007). Ecotourism certification in New Zealand: operator and industry perspectives. In R. Black \& A. Crabtree (eds.) Quality assurance and certification in ecotourism. CAB International: Oxfordshire, UK, 395-414.

Scarpi, D., Mason, M. \& Raggiotto, F., (2019). "To Rome with love: A moderated mediation model in Roman heritage consumption", Tourism Management, Vol. 71, pp. 389-401.

Schnitzer, M., Kössler, C., Schlemmer, P. \& Peters, M., (2021). "Influence of event and place image on residents' attitudes toward and support for events", Journal of Hospitality \& Tourism Research, Vol. 45 No. 7, pp. 1260-1281.

Sebhatu, S.P. \& Enquist, B., (2007). "ISO 14001 as a driving force for sustainable development and value creation", The TQM Magazine, Vol. 19 No. 5, pp. 468482.

Sharma, T., Chen, J. \& Liu, W.Y., (2020). "Eco-innovation in hospitality research (1998-2018): a systematic review", International Journal of Contemporary Hospitality Management, Vol. 32 No. 2, pp. 913-933.

Silva, C., Kastenholz, E. \& Abrantes, J.L., (2013). "Place-attachment, destination image and impacts of tourism in mountain destinations", Anatolia, Vol. 24 No. 1, pp. 17-29.

Smith, A., Brown, G. \& Assaker, G., (2017). "Olympic experiences: the significance of place", Event Management, Vol. 21 No. 3, pp. 281-299.

Steg, L. \& Vlek, C., (2009). "Encouraging pro-environmental behaviour: an integrative review and research agenda", Journal of Environmental Psychology, Vol. 29 No. 3, pp. 309-317.

Stylidis, D., Biran, A., Sit, J. \& Szivas, E.M., (2014). "Residents' support for tourism development: the role of residents' place image and perceived tourism impacts", Tourism Management, Vol. 45, pp. 260-274.

Sung, H., Kang, J.-H., Moon, S., Choi, J., You, M. \& Choi, I., (2021). "Emotional change, satisfaction and attachment to a sport mega-event: the PyeongChang 2018 Winter Olympics", Journal of Hospitality and Tourism Management, Vol. 48, pp. 240-247.

Tournois, L. \& Djeric, G., (2019). "Evaluating urban residents' attitudes towards tourism development in Belgrade (Serbia)", Current Issues in Tourism, Vol. 22 No. 14, pp. 1670-1678.

United Nations Environmental Programme, (2012). Sustainable Events Guide. UNEP DTIE Sustainable Consumption and Production Branch: Paris, France.

Wang, F., Wang, K. \& Wang, L., (2019). "An examination of a city greening megaevent", International Journal of Hospitality Management, Vol. 77, pp. 538-548.

Wang, S. \& Xu, H., (2015). "Influence of place-based senses of distinctiveness, continuity, self-esteem and self-efficacy on residents' attitudes toward tourism", Tourism Management, Vol. 47, pp. 241-250.

Zhou, Y. \& Ap, J., (2009). "Residents' perceptions towards the impacts of the Beijing 2008 Olympic Games", Journal of Travel Research, Vol. 48 No. 1, pp. 78-91. 
Table 1. Respondent profile

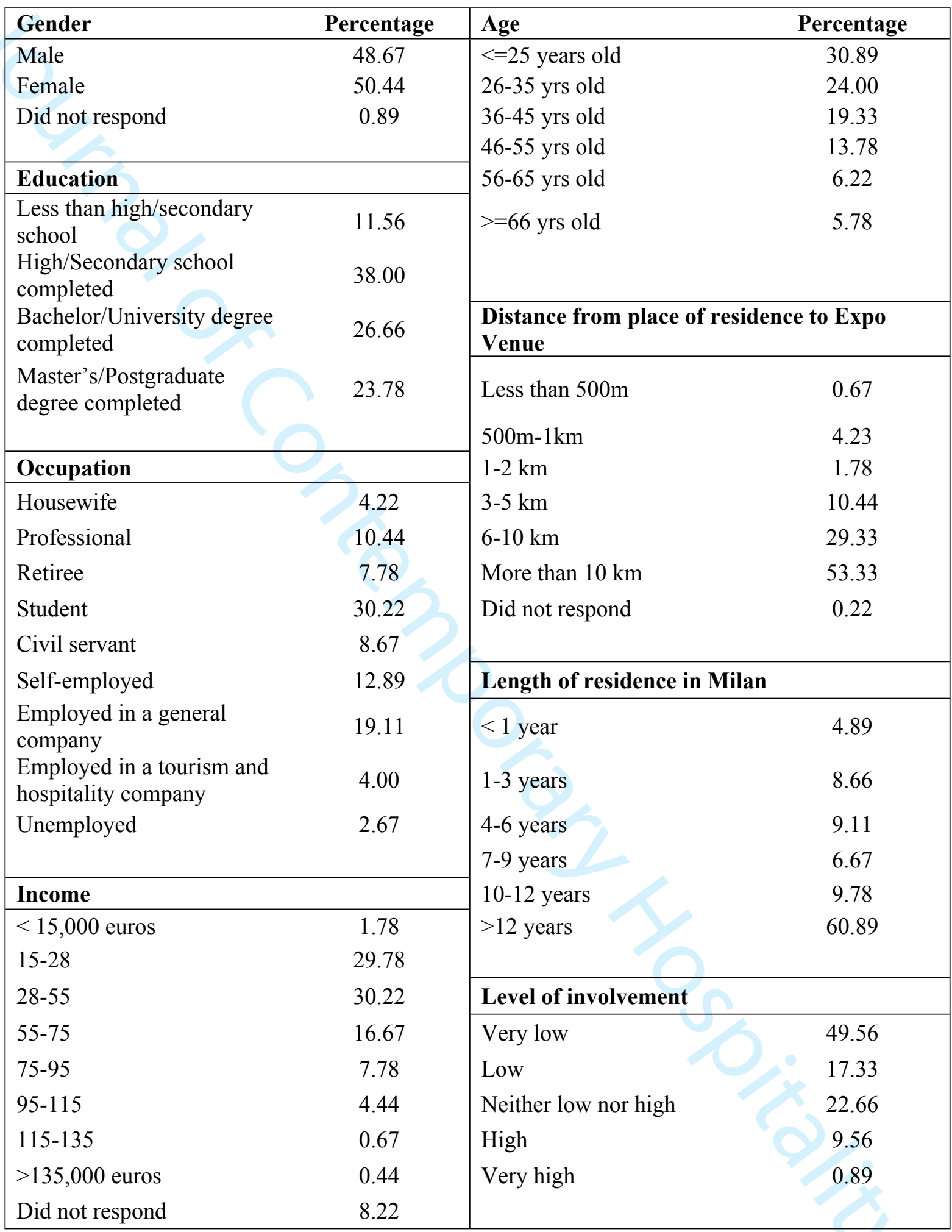


Table 2. Psychometric properties of constructs and items

\begin{tabular}{|c|c|c|c|}
\hline Constructs and items & $\begin{array}{c}\text { Std. } \\
\text { Loading }\end{array}$ & t-value & VIF \\
\hline \multicolumn{4}{|l|}{$\begin{array}{l}\text { Perceptions of Environmental Certification (PEC) } \\
(\alpha=0.855, \text { rho_A } A=0.858, C R=0.893, A V E=0.582)\end{array}$} \\
\hline PCert 1: CES will limit the increase in air pollution & 0.792 & 33.928 & 1.951 \\
\hline PCert 2: CES will limit the increase in littering & 0.706 & 23.335 & 1.605 \\
\hline PCert 3: CES will limit the damage for the natural environment & 0.815 & 46.927 & 1.999 \\
\hline PCert 4: CES will limit the increase in noise pollution & 0.794 & 37.861 & 2.055 \\
\hline PCert 5: CES will limit the increase in traffic congestion & 0.690 & 24.643 & 1.461 \\
\hline PCert 6: CES will limit the increase in visual pollution & 0.770 & 36.330 & 2.019 \\
\hline \multicolumn{4}{|l|}{$\begin{array}{l}\text { Positive Environmental Impacts }(\text { PEI }) \\
\left(\alpha=0.726, \text { rho_A }=0.753, C R=0.833, A V E=0.561 ; Q^{2}=0.155\right)\end{array}$} \\
\hline $\begin{array}{l}\text { Pos 1: Increase the culture of biodiversity in food for Milan } \\
\text { residents }\end{array}$ & 0.822 & 45.749 & 1.841 \\
\hline $\begin{array}{l}\text { Pos2: Increase the awareness of the importance of food and avoid } \\
\text { food waste }\end{array}$ & 0.766 & 29.798 & 1.449 \\
\hline Pos3: Increase the culture for healthy lifestyles for Milan residents & 0.842 & 53.127 & 1.869 \\
\hline Pos4: Stimulate planning and administrative controls & 0.525 & 11.320 & 1.103 \\
\hline \multicolumn{4}{|l|}{$\begin{array}{l}\text { Negative Environmental Impacts }(\mathrm{NEI}) \\
\left(\alpha=0.719, \text { rho_A }=\mathbf{0 . 7 5 2}, \mathrm{CR}=\mathbf{0 . 8 2 3}, \mathrm{AVE}=\mathbf{0 . 5 4 1}, \mathrm{Q}^{2}=\mathbf{0 . 0 4 5}\right)\end{array}$} \\
\hline Neg1: Increase air pollution & 0.660 & 12.820 & 1.332 \\
\hline Neg2: Damage the natural environment & 0.814 & 36.116 & 1.445 \\
\hline Neg3: Increase noise pollution & 0.800 & 34.563 & 1.599 \\
\hline Neg4: Increase visual pollution & 0.653 & 15.861 & 1.220 \\
\hline \multicolumn{4}{|l|}{$\begin{array}{l}\text { Event Support }(E S) \\
\left(\alpha=0.831, \text { rho_A }=0.838, C R=0.899, A V E=0.748, Q^{2}=0.309\right)\end{array}$} \\
\hline Sup1: I am excited about Milan hosting the 2015 Expo & 0.892 & 82.677 & 2.147 \\
\hline Sup2: I support the 2015 Expo as a resident & 0.869 & 63.256 & 1.930 \\
\hline Sup3: Milan should bid for other major business events & 0.831 & 39.341 & 1.773 \\
\hline \multicolumn{4}{|l|}{$\begin{array}{l}\text { Place Attachment (PA) } \\
(\alpha=0.895, \text { rho_A }=0.932, \mathrm{CR}=0.922,, \text { AVE }=0.702)\end{array}$} \\
\hline Att1: I identify strongly with my place of residence, Milan & 0.869 & 58.373 & 2.372 \\
\hline Att2: I feel this city is part of me & 0.892 & 76.572 & 2.651 \\
\hline Att3: This city says a lot about who I am & 0.835 & 44.544 & 2.334 \\
\hline Att4: I feel a strong sense of belonging to this city & 0.843 & 40.016 & 2.629 \\
\hline Att5: This city means a lot to me & 0.744 & 24.19 & 1.733 \\
\hline
\end{tabular}

Model fit: SRMR $=0.055$ 
Table 3. Discriminant validity

\begin{tabular}{|l|c|c|c|c|c|}
\hline Latent Constructs & PEC & PEI & NEI & ES & PA \\
\hline PEC & $\mathbf{0 . 7 6 3}$ & & & & \\
PEI & $0.515[0.655]$ & $\mathbf{0 . 7 4 9}$ & & & \\
NEI & $-0.252[0.300]$ & $-0.279[0.352]$ & $\mathbf{0 . 7 3 5}$ & & \\
ES & $0.468[0.549]$ & $0.556[0.716]$ & $-0.431[0.543]$ & $\mathbf{0 . 8 1 2}$ & \\
PA & $0.156[0.167]$ & $0.247[0.284]$ & $-0.171[0.195]$ & $0.308[0.351]$ & $\mathbf{0 . 8 3 8}$ \\
\hline
\end{tabular}

Note: Bold figures shows the square root of AVE, HTMT ratios are shown in brackets, PEC $=$ Perception of Event Certification, $\mathrm{PEI}=$ Positive Environmental Impacts, $\mathrm{NEI}=$ Negative Environmental Impacts, ES= Event Support, PA= Place Attachment

Table 4. Path coefficient, effect size and hypothesis testing

\begin{tabular}{|c|c|c|c|c|c|c|}
\hline \multirow{2}{*}{ Hypothesis } & \multirow{2}{*}{ Paths } & \multirow[t]{2}{*}{ Path coefficients (p-level) } & \multicolumn{2}{|c|}{$\begin{array}{l}\text { BCa Confidence } \\
\text { Intervals }\end{array}$} & \multirow{2}{*}{$\begin{array}{l}\text { Effect } \\
\operatorname{sizes}\left(\mathbf{f}^{2}\right)\end{array}$} & \multirow{2}{*}{$\begin{array}{l}\text { Hypothesis } \\
\text { Supported }\end{array}$} \\
\hline & & & $2.5 \%$ & $97.5 \%$ & & \\
\hline $\mathrm{H}_{1}$ & $\mathrm{PEC} \rightarrow \mathrm{PEI}$ & $0.491(\mathrm{p}<0.001)$ & 0.411 & 0.559 & 0.324 & Yes \\
\hline $\mathrm{H}_{2}$ & $\mathrm{PEC} \rightarrow \mathrm{NEI}$ & $-0.217(p<0.001)$ & -0.321 & -0.112 & 0.049 & Yes \\
\hline $\mathrm{H}_{3}$ & $\mathrm{PEI} \rightarrow \mathrm{ES}$ & $0.382(\mathrm{p}<0.001)$ & 0.287 & 0.474 & 0.184 & Yes \\
\hline $\mathrm{H}_{4}$ & $\mathrm{NEI} \rightarrow \mathrm{ES}$ & $-0.258(\mathrm{p}<0.001)$ & -0.339 & -0.173 & 0.103 & Yes \\
\hline $\mathrm{H}_{5}$ & $\mathrm{PEC} \rightarrow \mathrm{ES}$ & $0.186(\mathrm{p}<0.001)$ & 0.098 & 0.272 & 0.043 & Yes \\
\hline $\mathrm{H}_{6 \mathrm{a}}$ & PEC*PA $\rightarrow$ PEI & $0.012(p=0.726)$ & -0.059 & 0.080 & 0.000 & No \\
\hline $\mathrm{H}_{6 \mathrm{~b}}$ & $\mathrm{PEC} * \mathrm{PA} \rightarrow \mathrm{NEI}$ & $0.095(\mathrm{p}<0.05)$ & 0.002 & 0.186 & 0.012 & Yes \\
\hline
\end{tabular}




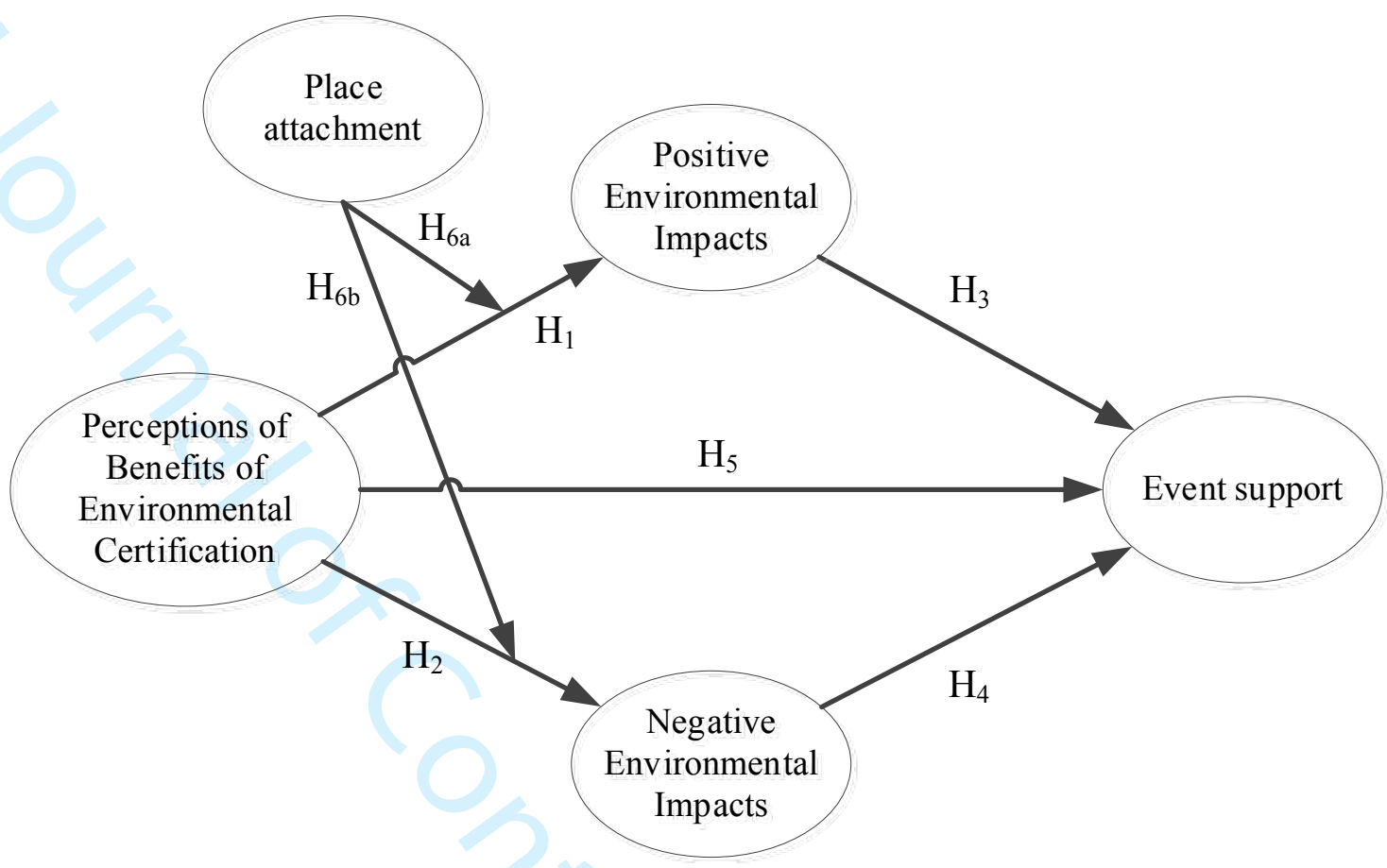

Figure 1. Conceptual Model of the Study

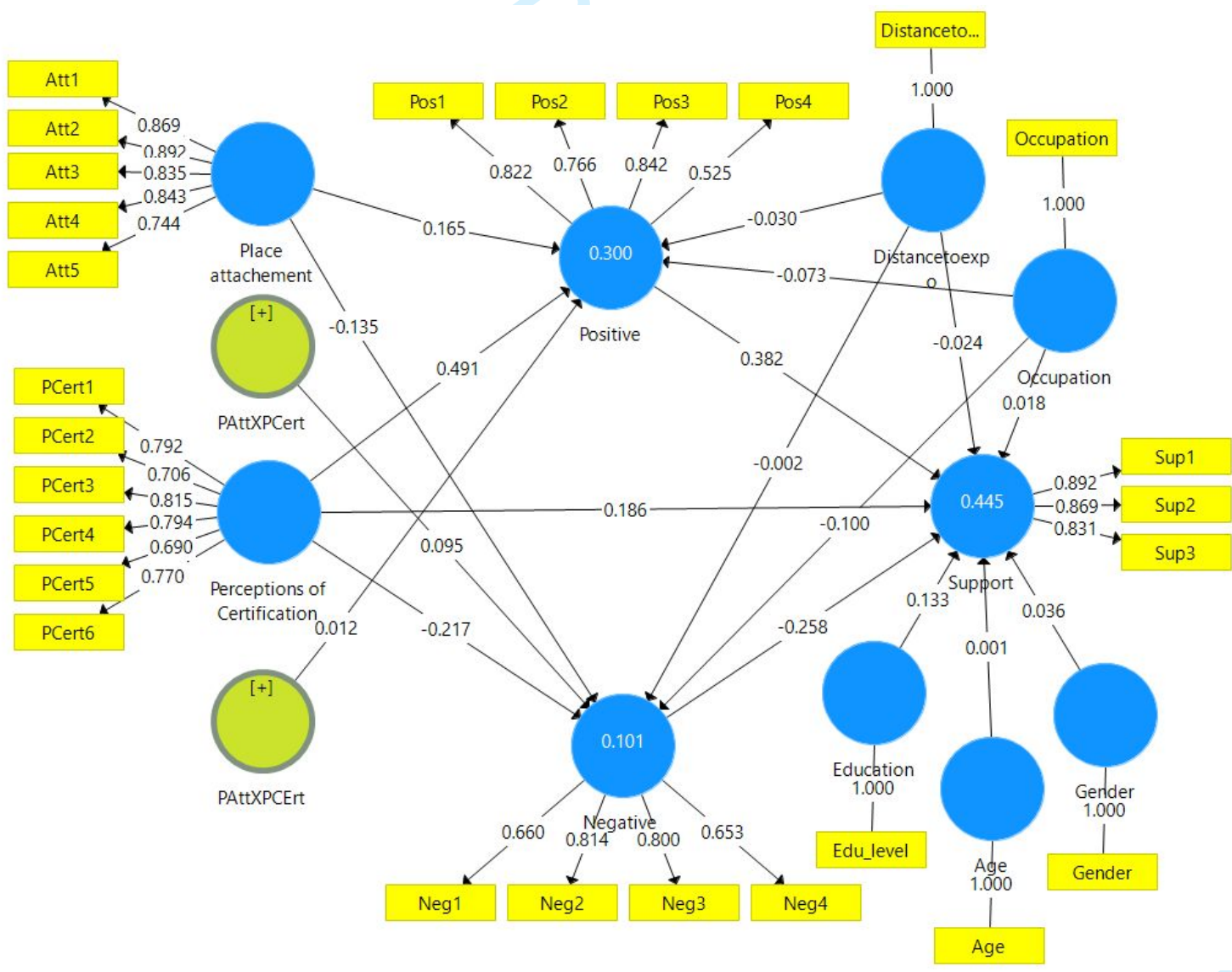

Figure 2. Structural model 


\section{INTERNATIONAL JOURNAL OF CONTEMPORARY HOSPITALITY MANAGEMENT}

Author Response Form

When revising your paper, please prepare this report explaining how you have responded to each reviewer's comments and suggestions specifically.

\section{Editor Comments}

\begin{tabular}{|c|c|}
\hline Suggestions/comments from the Reviewer & $\begin{array}{l}\text { Response from the } \\
\text { Author(s) }\end{array}$ \\
\hline $\begin{array}{l}\text { 1. Respond to one of our associate editors' and the reviewers' comments and revise } \\
\text { your article accordingly. }\end{array}$ & Done, see below \\
\hline $\begin{array}{l}\text { 2. Include a structured abstract in page } 1 \text { of the main document and make sure that it } \\
\text { includes all the required subsections including Purpose, Methodology, Findings, } \\
\text { Implications and Originality along with key words. }\end{array}$ & Done \\
\hline $\begin{array}{l}\text { 3. Make sure to follow IJCHM author guidelines closely: } \\
\text { http://emeraldgrouppublishing.com/products/journals/author_guidelines.htm?id=ijchm } \\
\text { For example, when there are three or more authors, you need to use Adam et al., XXXX } \\
\text { (or Adam et al., XXXX) format for the first time and after. You should list references } \\
\text { within text in an alphabetical order. }\end{array}$ & Done \\
\hline $\begin{array}{l}\text { 4. Revisit the Discussion and Conclusions sections one more time to better answer the } \\
\text { "So What" question. There should be four sub-sections under this section: (1) } \\
\text { Conclusions, (2) Theoretical Implications, (3) Practical Implications and (4) Limitations } \\
\text { and Future Research. }\end{array}$ & Done \\
\hline $\begin{array}{l}\text { 5. To strengthen your literature review and theoretical implications, you may like to } \\
\text { incorporate more recent and relevant references published in recent months/years. }\end{array}$ & Done \\
\hline $\begin{array}{l}\text { 6. Cross check all references within text with your reference list and make sure that all } \\
\text { references used in within text are listed in your reference list and remove any uncited } \\
\text { reference from the reference list. You must also make sure that each reference in your } \\
\text { reference list is accurate and complete in terms of authors' names, title, volume } \\
\text { number, issue number, pages, publisher etc. }\end{array}$ & Done \\
\hline $\begin{array}{l}\text { 7. Run your article through iThenticate, Crosscheck or any similar software to check the } \\
\text { similarity between your study and previous studies. Try to minimize similarity } \\
\text { percentage below } 1 \% \text { with any previous study. After you run your article's final version } \\
\text { through iThenticate or other similar software, you should upload the similarity report } \\
\text { to the system for our records. }\end{array}$ & Done \\
\hline 8. Keep your article below 10000 words including references, tables and figures. & Done \\
\hline $\begin{array}{l}\text { 9. Make sure that the flow of your article is improved. We do not prefer short } \\
\text { paragraphs with one-three sentences or long paragraphs longer than half page. }\end{array}$ & Done \\
\hline $\begin{array}{l}\text { 10. Proofread your article one more time and also you may ask a technical writer/copy } \\
\text { editor to proofread it for you. After the manuscript is accepted, we will not ask you to } \\
\text { proofread it again. In short, after I send you an official acceptance e-mail, you will not } \\
\text { be able to make any further changes in your manuscript. }\end{array}$ & Done \\
\hline $\begin{array}{l}\text { 11. Make sure you have all the coauthors, acknowledgements, tables and figures } \\
\text { included in your submission. You must also make sure that order of authors, their full } \\
\text { names, their affiliations and email addresses are accurate. We cannot make any } \\
\text { changes after the paper is accepted. }\end{array}$ & Do \\
\hline $\begin{array}{l}\text { 12. You should not add a new coauthor(s) at this stage unless there is a legitimate } \\
\text { justification. }\end{array}$ & Not applicable \\
\hline $\begin{array}{l}\text { 13. Submit a clean version of your paper. You don't need to show/highlight all the } \\
\text { changes made in the paper. I will read its final version anyway. }\end{array}$ & Done \\
\hline $\begin{array}{l}\text { 14. In addition to responding to the reviewers' comments, you should prepare and } \\
\text { submit a brief report showing how you have responded to the above requests as well as } \\
\text { the associate editor's comments. When revising your submission, you don't need to } \\
\text { show/highlight all the changes made in the paper. I will read its final version anyway. }\end{array}$ & Done \\
\hline
\end{tabular}




\title{
INTERNATIONAL JOURNAL OF CONTEMPORARY HOSPITALITY MANAGEMENT
}

\author{
Author Response Form
}

REVIEWER 3

\begin{tabular}{|l|l|}
\hline Suggestions/comments from the Reviewer & Response from the Author(s) \\
\hline $\begin{array}{l}\text { 1. P.44 (line 14) 'The expo was a ...' should read as 'The } \\
\text { expo. was a ...' }\end{array}$ & corrected \\
\hline 2. Cheung et al. (2014) - Issue no. was not indicated & Done \\
\hline $\begin{array}{l}\text { 3. Ludvigsen et al. (2020) - Vol no. and issue no. were } \\
\text { not indicated }\end{array}$ & Article in press, doi now provided - \\
\hline 4. Raggiotto et al. (2021) - Issue no. was not indicated. & Done \\
\hline
\end{tabular}

\section{Associate Editor}

\begin{tabular}{l}
\hline Suggestions/comments from the Reviewer \\
\hline 1. This is an interesting study on an important topic. \\
The study can benefit from a strong copy-editing. The \\
theoretical foundation and theoretical implications \\
should be improved further. The following studies can \\
help the authors with this task. Below studies are just \\
suggestions and the authors may find similar relevant \\
and recent studies.
\end{tabular}

2. Sharma, T., Chen, J. and Liu, W.Y. (2020), "Ecoinnovation in hospitality research (1998-2018): a systematic review", International Journal of Contemporary Hospitality Management, Vol. 32 No. 2, pp. 913-933. https://doi.org/10.1108/IJCHM-01-2019-0002

Chan, J., Gao, Y.(L). and McGinley, S. (2021), "Updates in service standards in hotels: how COVID-19 changed operations", International Journal of Contemporary Hospitality Management, Vol. 33 No. 5, pp. 1668-1687. https://doi.org/10.1108/IJCHM-09-2020-1013

Aboramadan, M. and Karatepe, O.M. (2021), "Green human resource management, perceived green organizational support and their effects on hotel employees' behavioral outcomes", International Journal of Contemporary Hospitality Management, Vol. 33 No. 10, pp. 3199-3222. https://doi.org/10.1108/IJCHM-12-2020-1440

Mariani, M. and Borghi, M. (2021), "Are environmentalrelated online reviews more helpful? A big data analytics approach", International Journal of Contemporary Hospitality Management, Vol. 33 No. 6, pp. 2065-2090.

https://doi.org/10.1108/IJCHM-06-2020-0548

Assaker, G. (2020), "The effects of hotel green business practices on consumers' loyalty intentions: an expanded multidimensional service model in the upscale segment", International Journal of Contemporary Hospitality Management, Vol. 32 No. 12, pp. 3787-3807. https://doi.org/10.1108/IJCHM-05-2020-0461

González-Rodríguez, M.R., Díaz-Fernández, M.C. and Font, X. (2020), "Factors influencing willingness of customers of
Response from the Author(s)

We have edited the manuscript further and incorporated some of these suggested studies, bearing in mind the word limitations imposed by the journal.

We have incorporated the article by Sharma et al. (2020) in the discussion of the results and literature review.

We did not find this article relevant in any way to our manuscript.

We have added this article by Aboramadan and Karatepe in the discussion of results.

We have added this article to the discussion/implications section of the manuscript

We have added this study to the literature review

We have added this article to the discussion 


\section{INTERNATIONAL JOURNAL OF CONTEMPORARY HOSPITALITY MANAGEMENT}

Author Response Form

environmentally friendly hotels to pay a price premium", International Journal of Contemporary Hospitality

Management, Vol. 32 No. 1, pp. 60-80.

https://doi.org/10.1108/IJCHM-02-2019-0147

Pekovic, S. (2021), "Green pull motives and overall tourist satisfaction: a macro- and micro-levels analysis", International Journal of Contemporary Hospitality

Management, Vol. 33 No. 4, pp. 1368-1390.

https://doi.org/10.1108/IJCHM-06-2020-0609

Hossain, M.S., Hussain, K., Kannan, S. and Kunju Raman Nair, S.K. (2021), "Determinants of sustainable competitive advantage from resource-based view: implications for hotel industry", Journal of Hospitality and Tourism Insights, Vol. ahead-of-print No. ahead-of-print.

https://doi.org/10.1108/JHTI-08-2020-0152

We did not find this article useful as the key findings relate more to customers rather than residents

We did not find this article useful 


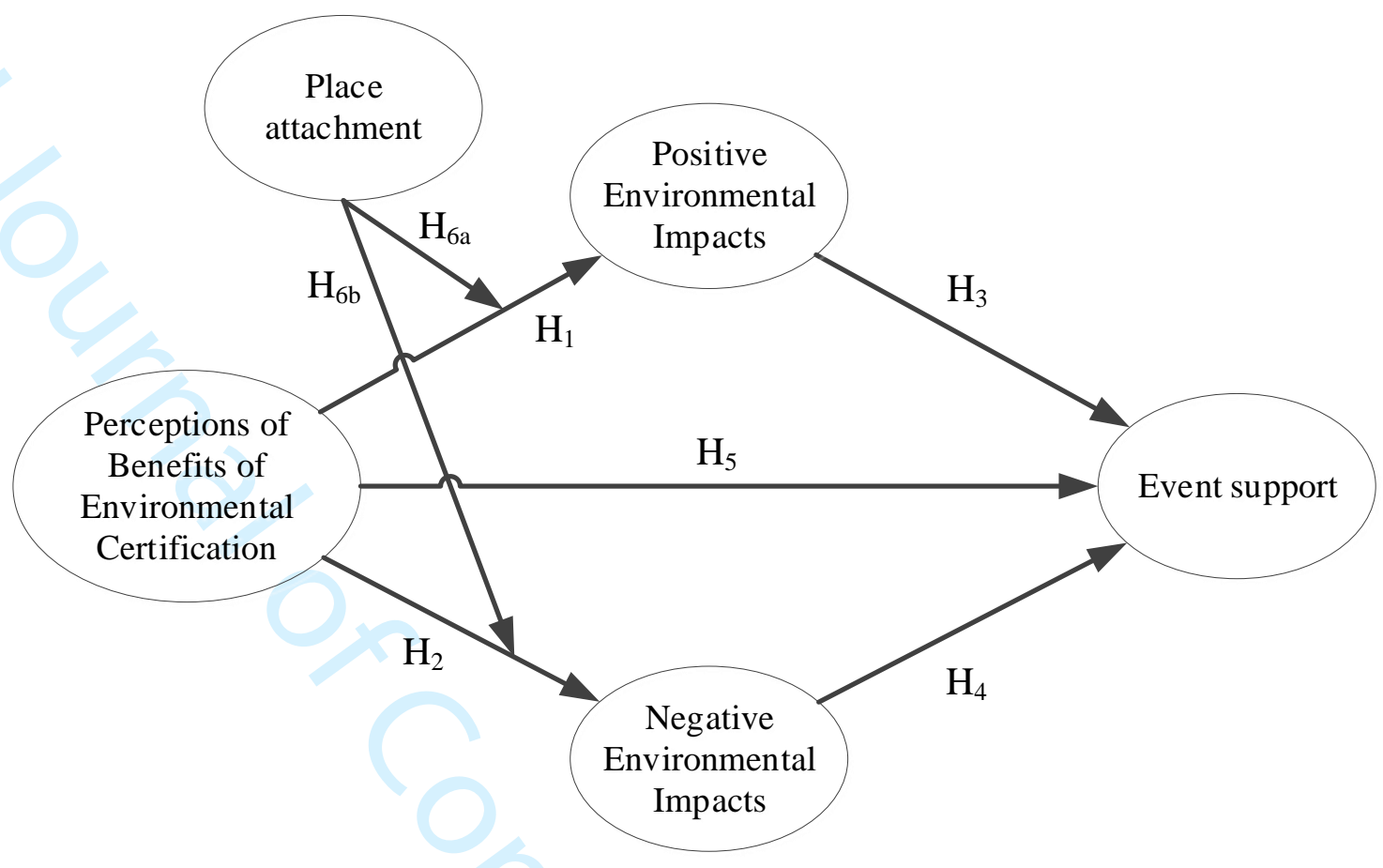

FIGURE 1 Conceptual Model of the Study 


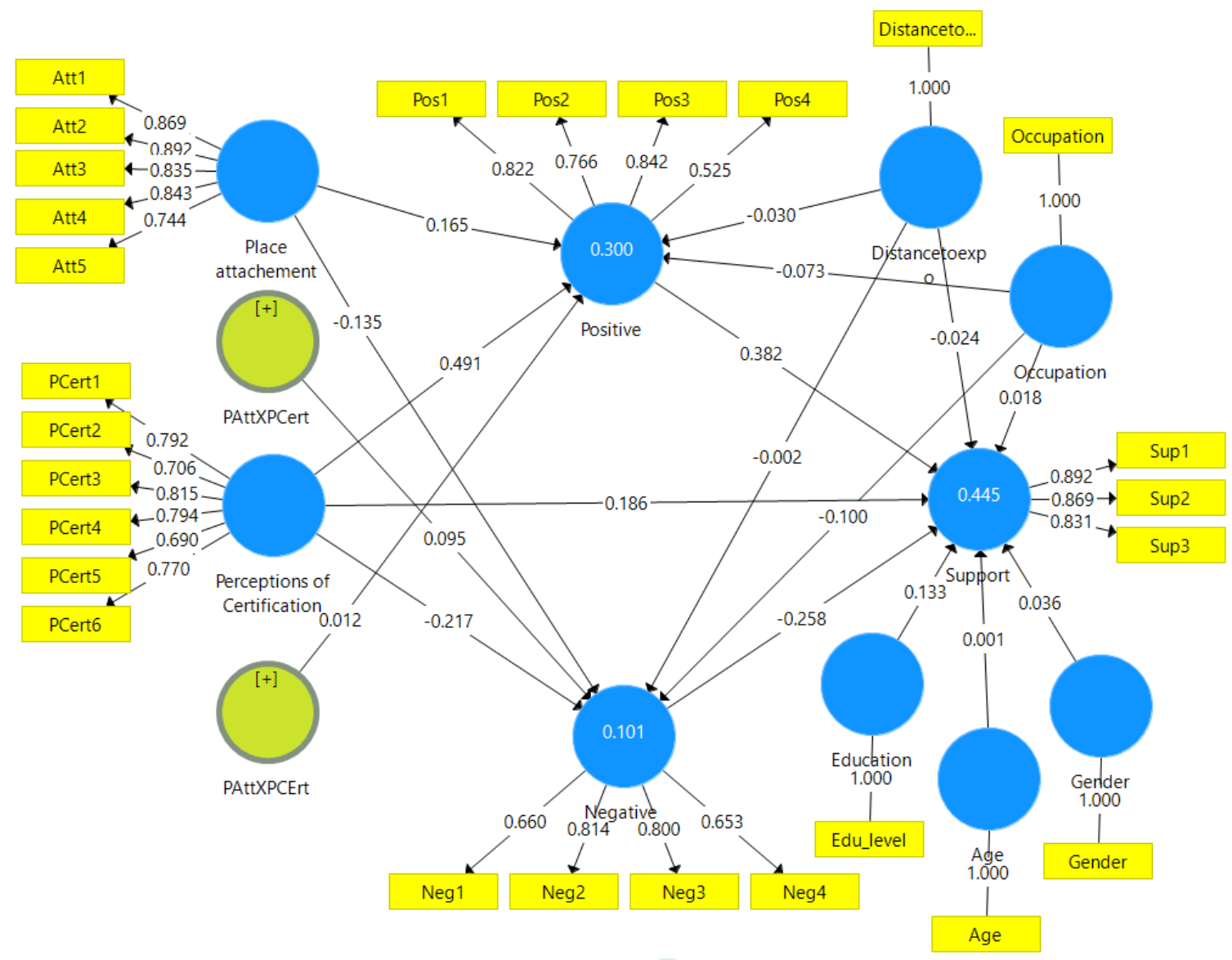

FIGURE 2 Structural model 